\title{
Remembering Bonegilla: The Construction of a Public Memory Place at Block 19
}

BRUCE PenNay

B onegilla Camp was one of several military training centres hastily erected shortly after the commencement of the Second World War. It was a sizeable hutted camp capable of housing up to 6000 personnel. In 1947 it was selected as a reception and training centre for the first contingents of Displaced Persons that Australia agreed to take under an agreement with the International Refugee

Organisation. Bonegilla continued as a reception and training centre for Displaced Persons, other refugees and assisted migrants through to 1971. It was the largest and longest-lived reception centre in postwar Australia, taking in about 309,000 new arrivals. As most of the newcomers arriving in Australia via Bonegilla were drawn from nonEnglish-speaking European countries, Bonegilla had close association with the immigration policy shift away from prioritising Anglo-Celtic 
sources. That shift was to transform political and social expectations of the cultural diversity of Australia. ${ }^{1}$ The Block 19 remnant of Bonegilla was placed on the Register of the National Estate (RNE) in 1990, the Victorian Heritage List (VHL) in 2002 and the National Heritage List (NHL) in 2007. The site has powerful connections for many people. ${ }^{2}$

In this article I trace the emergence of Block 19 Bonegilla as a listed heritage site. Heritage listings are a form of official public history: they identify and proclaim government-sanctioned memory places. Listed places are publicised as important to the community trying to understand its development. They are provided with protection from demolition or radical change and get special access to conservation and interpretation funding. In the first section I provide a brief chronology of the development of Block 19 as a heritage place, important to the state and the nation. I point to some broad shifts in official heritage value through the sequence of three different heritage listings. In the second section I focus on how the National Heritage Listing differs from the earlier two. This listing represents a shift in the scale of regard and re-shapes site storytelling. ${ }^{3}$ The third section takes up the point that of all the sites currently on the National Heritage List, Bonegilla has special claims to be a public memory place. I attempt some analysis of the principal memory sources that the interpretation of Bonegilla draws upon. Finally I look to ways the site is presented and perceived.

In writing this article I am explaining how the Bonegilla Migrant Experience Heritage Park Steering Committee, of which I am a member and the Albury LibraryMuseum, where I provide research services as a consultant, read and try to respond to shifts in the definitions of Bonegilla's significance. I have elsewhere outlined how the custodians of Bonegilla have tried to attract tourist and local visitors. Much of their efforts to promote the place depend on reading and responding to the expectations of tourist and local visitors. ${ }^{4}$ This article is about the first interpretation step - deciding on significance.

ATTRIBUTING HERITAGE VALUE

Between 1987 and 2007 Block 19 Bonegilla changed from being an undistinguished and somewhat neglected group of army huts into a place of 'outstanding heritage value to the nation': it became 'a symbol of post-war migration which transformed Australia's economy, society and culture'. The three heritage listings punctuate 
this transformation. Beyond, but associated with those listings, there were other commemorative developments that illustrate and bear on this shift in public regard.

The first heritage listing on the RNE in 1990 saved the last remaining 28 huts at Block 19 from demolition. The Army had reoccupied Bonegilla when the reception centre closed in 1971. Between 1978 and 1982 it demolished most of the buildings to make way for a new development. In 1986 it met opposition to its proposal to demolish some of the last remaining huts. A group of former migrant centre residents had floated the idea of establishing a National Immigration Museum at Bonegilla and protested against the proposed demolition. Support for the retention of the buildings and for a museum grew when the museum group organised a well attended Back-to-Bonegilla festival in $1987 .{ }^{5}$

In April 1988 the Australian Heritage Commission agreed to place the site on the Interim Register of the National Estate. The Army objected partly because of the inconvenience a heritage site might cause, partly because the military history of the site might be marginalized or even submerged: 'If Block 19 is to be listed on the Register of the National Estate, it should be for its military significance and not for the minor role that it played in post-war

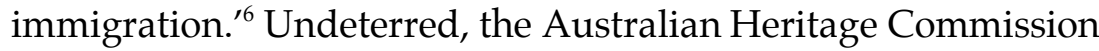
proceeded with the listing, but was politic. The listing acknowledged the importance not only of the migrant centre but also of the former army training camp during the Second World War and during the Vietnam War. Bonegilla had 'strong cultural value to sections of the migrant community'; it was 'also valued by the army community'.

Once the heritage listing had been made, the Army agreed to give the museum group permission to proceed with a museum through a lease or permissive occupancy arrangement for Block 19. However, the museum group could not muster sufficient local support and disbanded. Block 19 remained with the Department of the Army which continued to use it for training purposes. A Conservation Management Plan was prepared in 1996 and not long afterwards the Army agreed to transfer the site to the Victorian Government.

The Albury Regional Museum accepted the artefacts collected by the museum group and made concerted efforts to collect memorabilia. Museum director, Elizabeth Close, was the prime 
mover behind the organisation of a successful ten-day fiftieth anniversary festival in 1997. That event helped attract wide notice and additional government funding for exhibition development and a site interpretation plan. Another smaller-scaled festival event was held in 1999. In 1987, 1997 and 1999 ethnic groups organised dance, music and food. The museum collected more and more memory pieces. Reunions reinfused remembering.

From 1987 to 2002 nearly all the site visitors were pilgrims. Former residents made return visits. Their children came 'to place their parents as well as their own lives in a historical context'. ${ }^{7}$ There was a steady stream of visitors to view and add to the migrant memorabilia repository at Albury Regional Museum. Management of the site was passive. Interpretation was primarily event-led with ethnic organisation based festivals.

After the Army transferred the site to Victoria in 2001, the state government listed the site on the Heritage Victoria Register as a place of state significance. For Victoria, 'Block 19 was of historical and social significance for its central role as part of the Bonegilla Migrant Reception Centre in the most far-reaching demographic change in Australia after the Gold Rush - the post Second World War immigration programme.' However, this second listing, like the first, looked to Bonegilla's importance as an army camp as well as a migrant centre. Indeed, the listing went further in explaining the historic significance of the army camp. Block 19 was 'a remnant of the expansionist phase of defence building activity which took place at the commencement of the Second World War.' It was also 'a remnant of the logistical and organisational expansion of the Army during the Vietnam War'. There was more detailed explanation of changes in its role as an army camp.

While the listing gave new emphasis to the army origins of the place, government funding put the emphasis on the former migrant centre. The Victorian Government provided \$2 million for establishing a commemorative centre and tourism venue at Block 19. In the same year, Albury Regional Museum launched a travelling exhibition, From the Steps of Bonegilla, which attracted large supplementary exhibitions drawn, in Melbourne, from materials donated to the Immigration Museum and, in Canberra, from the National Australian Archives. The former Bonegilla migrant reception and training centre was growing in renown and its memory bank was increasing. 
Block 19 was readied for tourists as well as pilgrims. With the $\$ 2$ million it had allocated, the state government built an interpretation pavilion and a café. The Bonegilla Migrant Experience Heritage Park opened with a festival event in December 2005. Visitors to the heritage park were subsequently able to inspect the site on any day, not just at festival time. They could access the interpretation pavilion with static information panels and a twenty-minute film clip. In keeping with the Heritage Victoria Register listing, the stories told were about the place as an army training camp as well as a migrant centre.

The second listing on the Heritage Victoria Register had greater impact than the first. With it there were considerable changes to the way the site was presented. The first listing did save the site from demolition, but the importance of the first listing waned with a lack of government commitment to the Register of National Estate. The Register had been a bold attempt to compile a comprehensive list of 'places we want to keep'. A creation of the Commonwealth Government, it attracted no clear funding support for conservation or promotion. The list of 13000 places had become unwieldy. The Register was frozen in February 2007: nothing was to be added or deleted beyond that date. Both the Commonwealth and the states preferred more selective listings which could be used to target funding support. Comparative value became more important in a hierarchy of significance that moved from local to state and then national levels. The Commonwealth reserved its attention for a newly composed short list of outstanding places.

The third listing on the NHL at the end of 2007 pushed commemorative place development even further than the first two by framing Block 19 as a national memory place. Bonegilla was declared one of a small number of historic sites that were of outstanding significance to the nation as a whole. It joined Captain Cook's Landing Place, Port Arthur, Eureka Stockade and Ned Kelly's Glenrowan, for instance, as part of the government approved stories of the making of the nation. ${ }^{8}$ The states had listed migrant accommodation centres within their borders, each important to the listing state - for example Maribyrnong in Victoria, Mayfield in New South Wales and Northam in Western Australia. Block 19 Bonegilla, however, was, of outstanding national significance, principally because of the former migrant centre's size and long life and also 
because of the comparatively substantial amount of fabric that remained. This place was selected as 'a symbol of post-war migration which transformed Australia's economy, society and culture'.

\section{DECIDING ON SIGNIFICANCE}

Heritage listings provide guidance on unravelling and presenting the stories of sites and buildings. The pithy gazetted statements of significance indicate the salient features that guide interpretation. There are variations in the three listings that arise from and prompt different remembering. They point to different storylines that stretch to, through and from Bonegilla.

In part the differences in the three listings reflect changes to the heritage listing process over the last twenty years. The National Heritage List grew, as explained, from government's need to adopt a more selective approach to heritage than that which had applied in developing the Register of the National Estate. Further, the listing process reflected rethinking about and adjustments to the Burra Charter. Heritage value 'moved from a focus on fabric to more clear inclusion of setting, use, association, records, related places and related objects'. ${ }^{9}$

At another level, explanation of the listing differences may reflect shifts in the social context in which memory is being forged. 'Remembering', John Bodnar suggests, 'is a collective activity designed to draw from the past details that will explain the here and now' ${ }^{10}$ Debates on recent immigration policies and practices and anxieties about multiculturalism may have prompted shifts in the emphasis given within stories about the mass post-war immigration program. Perhaps historians have challenged or deepened our understandings of immigrant arrival and settlement processes. ${ }^{11}$ That kind of analysis awaits someone more confident than I am of detecting fine trends in narratives of the nation over the brief twentyyear time span of these heritage listings. But I do want to indicate how the differences between the listings impact on storytelling about the place.

The National Heritage Listing of 2007 builds on and refines the two earlier listings in five ways. Paradoxically the overall effect of the NHL refinements is to sharpen storytelling but widen possible meanings.

First, the NHL states that Block 19's significance to the nation rests solely on its reception centre role. By way of contrast, the other 
two listings, especially the VHL, promoted the site's connection with the defence as well as the peopling of Australia. The NHL listing is concerned with these army origins primarily for what they meant to the refugee and migrant experience. Plainly the location, isolated from cities and distant from the nearby country towns of Albury and Wodonga, set the centre apart and added to the impression that newcomers were not quite part of the community. This isolation of Bonegilla and the rudimentary nature of the military-styled accommodation may have strengthened the pressure on migrants to take up employment offers.

The Army provided more than physical structure. The immigrants and army personnel shared the site for much of the time the reception centre operated. Initially former services personnel managed the reception centre along fairly regimented military lines. A uniformed Commandant (later Director) greeted new arrivals. Until it left the site to sole immigration uses in 1949, the Army provided cooking, transport and other services. In the late 1960s the Army returned for a second co-location phase taking over several blocks to accommodate units training National Servicemen for Vietnam. Assisted migrants expressed unease about the military setting and presence in the second co-location phase. Many refer to the accommodation as 'barracks' and the centre as a 'camp' in their memory pieces: 'Bonegilla was a military camp not suited for families'; the presence of armed soldiers has not been forgotten. ${ }^{12}$

Secondly, unlike the other two listings, the NHL refers to the newcomers as both refugees and migrants. Those who came as refugees, particularly the Displaced Persons, tend to remember the centre differently from the assisted migrants. Generally they had fewer complaints. After enduring labour and/or refugee camps in Europe they enjoyed the abundance of food. They were more forgiving of the shortcomings in the level of accommodation. They do not seem to have been troubled by the proximity of the Army. The displaced recall they 'were just happy to get out of the war'. ${ }^{13}$ Wanda Skowronska reads the centre as her displaced parents had seen it: 'these empty spaces housed people with dreams - their dreams not of gold but respite, perhaps some sanity and peace.' For her, the surrounds were 'bushy, hilly, picturesque and secure' ${ }^{14}$ The displaced dismiss the complaints that later cohorts of assisted passage migrants had of Bonegilla. They saw the assisted as mere 'economic migrants', 
who, unlike refugees with few other ports of repair, could even suggest that Bonegilla was a place of 'no hope'. ${ }^{15}$

Thirdly, the NHL differs from the VHL on curtilage. The NHL like the RNE included the whole 14.5ha that the Commonwealth had transferred to Victoria as Block 19 in 2001. The VHL confined its listing to a pocket of land containing only the huts: buildings not surrounds were its prime focus. The extension of the curtilage to include the open paddock surrounds draws on memory. Migrant photographs and memory pieces return time and again to mention the wide open spaces around Bonegilla and the nearby river. The local media made much of the role played by the physical setting in Australianising the newcomers. It was on long walks about Bonegilla that the newcomers came to understandings of their new country. The wider curtilage recognises that this place was Australia for them - the heat, the cold, the sun, the flies, the sense of isolation and bareness. ${ }^{16}$

Fourthly, again unlike the other two listings, the NHL pays specific attention to the way in which the site 'represents the role of the host society'. Block 19 Bonegilla prompts questions not only about what newcomers made of Australia, but also what Australia made of them in providing this facility. It demonstrates how Australia went about taking in strangers at a time when government did decide who will come into Australia and the circumstances in which they came.

The non-British were never as acceptable as the British who already had the language and whose work qualifications were recognised. The standard of accommodation offered British immigrants was superior to that offered the non-British. Indeed, there was a rush of improvements made before a small number of assisted migrants from the Britain were housed briefly at Bonegilla in 1951-52. Officials expected only the non-British to endure family separation when accommodation grew tight. Non-British women and children were sent from Bonegilla to Holding Centres, such as those at Uranquinty, Benalla or Cowra, when there was only room for those in jobs. By way of contrast, the British were housed in family hostels and were eligible for Housing Commission accommodation. Memory of the privilege given the British rankled with some. ${ }^{17}$

More widely, host society attitudes towards immigration were changing. Bonegilla reception centre spanned the years when Government policy slid from assimilation to integration, but that 
slide took place beyond Bonegilla. The local host society that had immediate contact with the reception centre recalls being well disposed to the newcomers. The migrants themselves generally maintain that the host society seemed indifferent rather than friendly or hostile. ${ }^{18}$

Last, the NHL looks beyond place to include the oral and written records associated with the site, for they 'yield insights into post-war migration and refugee experiences'. All places on the National Heritage List are in a sense memory places, but specific mention of the records related to them are rare. Perhaps it was Bonegilla's links with living memory that attracted this attention.

Official records, held principally at the National Australian Archives, provide understandings of post-war immigration policies and practices. They include the personal record cards of all Bonegilla arrivals and detail of the centre's administrative processes. Unofficial records abound principally in the Bonegilla Collection at what is now Albury LibraryMuseum and in the photographs at the State Library of Victoria. The Bonegilla Collection is primarily a memory bank of written memory pieces, photographs, objects, print materials and documents. It is the repository former residents chose to keep record of their experience of arrival and early settlement processes. There are sustained narratives in books, articles and web pages and some lengthy interviews in newspaper clippings. Most of the memory pieces are fragmentary - brief comments of a few lines or, at most, a few paragraphs on a 'tell-of-your-most-vivid-memory' form or in a visitor book. Like other visitor book entries those at Block 19 can be abrupt, scribbled in haste, clichéd and formulaic. One entry can set the precedent for those that follow. ${ }^{19}$ Nevertheless, these written memory fragments add to understandings of the character of the centre - its natural and cultural settings - from the point of view of the reception centre residents.

The listing on the NHL has impact on place story telling. It suggests examination of resident responses to being accommodated in a former defence establishment where not only the fabric and accoutrements were military-styled, but also the centre was organised on military lines. It suggests separate consideration be given to refugees as a category of the migrant intake. It emphasises the impact of location of the site on migrant experiences. It asks for analysis of host society responses to the newcomers and seeks 
explanation of differences between the reception of Non-British and British migrants. It prompts attempts to probe memory records.

In spite of any differences, all three heritage listings see the importance of the site to its former residents and their children. Migrants have, as expected, reclaimed the place as their special place. It is their Australian landing place: it is their memory place. ${ }^{20}$ Bonegilla is still a commemorative site at which there can continue to be celebrations of cultural diversity with parades of the tastes and smells of ethnic food, the twirls and rhythms of ethnic dance groups. But in line with the NHL prompting, it taps a variety of memories of migration and reception. Those memories are scrutinised as well as collected. Museum, site custodians, former residents and their children are actively engaged not only in guarding memory but also in its critical analysis. ${ }^{21}$

\section{PROBING MEMORY RECORDS}

The initial National Immigration Museum group had hoped not only to save original buildings but also to gather oral histories 'from those whose experience is first hand'. Official documentation would not be sufficient to capture what immigration had meant to those involved in it. Refugee and migrant narratives would more reliably portray arrival procedure as newcomers experienced them. ${ }^{22}$ However, immigrant memory banks here, as in the USA, yield contested histories. ${ }^{23}$ The histories told by immigration officials and those told by the migrant residents are not always in agreement. Further, migrant experiences vary according to background, language skills, time of arrival, age and gender. As Nonja Peters found with her interviews of post-war migrants to Western Australia, migrant memories are also influenced by the context in which they are retrieved. Retrospective understandings do not always match contemporary observations. ${ }^{24}$

\section{Visual records}

Visual records play a big part in promoting and interpreting the site. Plainly visitors find visual evidence comparatively easy to access and process. Photographs carry what many see as authentic, raw unprocessed history. Further, they shift focus 'from laws, statistics, administrators and government to people'. ${ }^{25}$ They provide opportunities for visitors to contrast official and unofficial representations. 


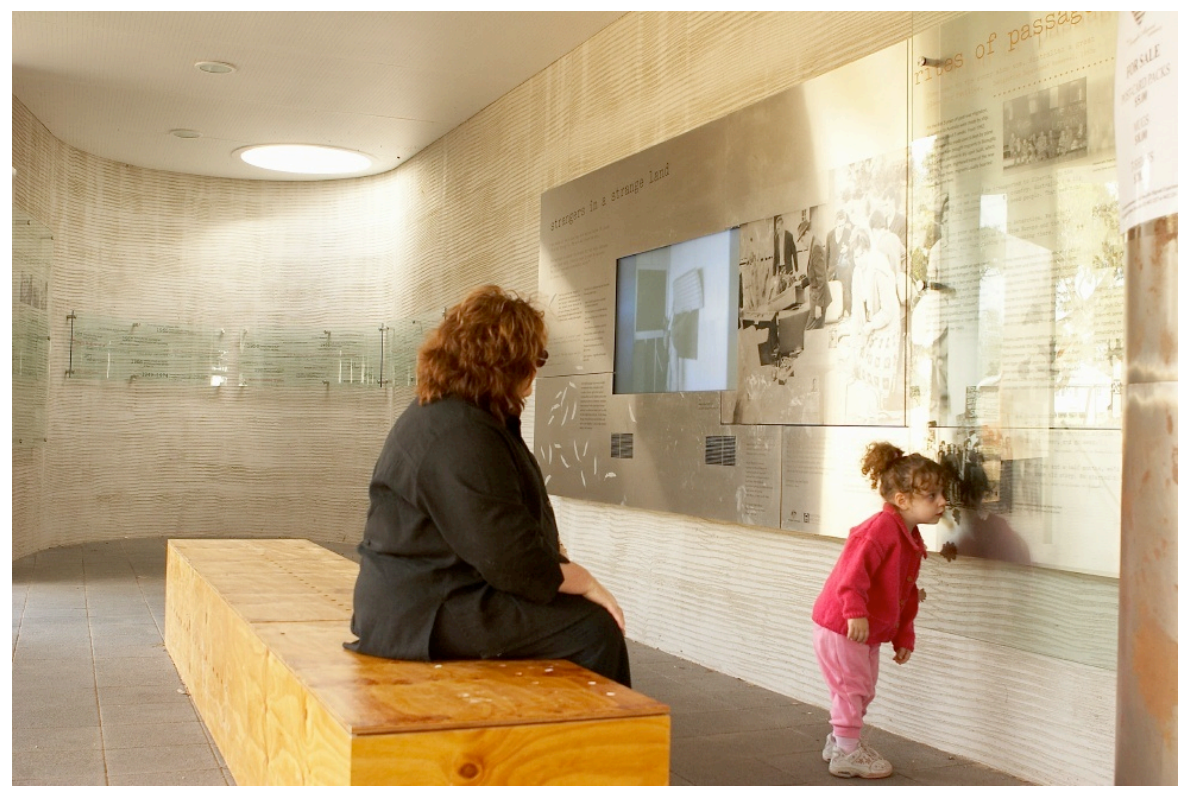

Visitors at the Beginning Place interpretation centre, Bonegilla, 2006 (Photograph Department of Sustainability and Environment)

Official photographs taken by government photographers from the Department of Information then Australian News and Information Bureau are accessible from the National Australian Archives in Canberra, but they are still held in annual volumes at the Department of Immigration. A departmental index groups them as illustrative of celebratory milestones and migrant success stories. There are many photographs on the economic contribution of the migrant workforce. Migrant achievements in musical, literary and sporting fields are celebrated. These photographs were intended to keep the Australian public favourably disposed towards the immigration program and were plied to the media for that purpose. ${ }^{26}$

The photographs taken of the various accommodation centres have the same promotional intent. They show the accommodation centres in a favourable light and illustrate the efficiency and effectiveness of the reception processes. At Bonegilla, as at other centres, numerous photos were taken of migrant children enjoying specially prepared facilities. Australia plainly took good care of the young. However, incidental detail in the images also conveys unintended messages. They show, for example, how the communal washrooms provided for defence force personnel were inadequate for migrant families. Loud speakers and notices in the periphery of photographs suggest the bureaucratic way the centre was conducted. 
The power points loaded with double adapters and the camp beds with slim mattresses show how austere the private living quarters were. The many portraits of the Queen and the ever present Union Jack show how the non-British were being prepared for life in a British-Australia.

Resident photographs focus principally on family and friends. They show groups congregated on the steps outside the huts. Some show how with minimal decorative pieces and resources they crafted personal space within the huts while living in a communal setting. Some show pride in new possessions such as a bike, a primus stove or even a car. Many show outings along Lake Hume. In so far as photographs fix as well as prompt remembering, Bonegilla, it seems, has enduring associations with bare feet and wet costumes. But again as with the official photographs, intention is important. What lay behind shaping an image for a future self or family or for those left behind?

Oral and written records

As often happens in oral history, participant narratives do not always match official accounts. So for example, the accounts Italian demonstrators gave of the Army's involvement in containing a violent demonstration in 1952 differ from official versions of events. Such discrepancies alert visitors to the need for a critical approach to testimony. They draw attention to different interpretations of cause and effect of this incident and a similar protest in $1961 .^{27}$

It is not only the official and the migrant accounts of events and life at Bonegilla that differed. The oral and written records indicate a kaleidoscope of refugee and migrant experiences and responses to the reception processes:

The Bonegilla Centre meant different things to different people - a curate's egg sort of place. To some it was a place of peace and plenty after years as conscripts in German factories on starvation rations, a place where one could roam at will, where one was close to the sky and Nature. To others it was an isolated place in the middle of nowhere from which they couldn't get away fast enough (Marie Ashley, language instructor 1949). ${ }^{28}$ 
Multi-voiced sources yield different insights. As the ICOMOS Charter acknowledges, 'places have a range of values for different individuals and groups' ${ }^{29}$

In general longer-term worker residents seem to have retained more favourable impressions of Bonegilla than those who were shortterm transients. Those who accepted jobs at the centre were prepared to accept its shortcomings. Accommodation costs were low. The job was known and less risky than a job elsewhere. Married couples with two jobs at the Centre could avoid separation. Staff had separate more comfortable staff blocks supplied with a richer diversity of food rations. They had access to a flood-lit tennis court and a bowling green. They organised bowling, basketball, soccer and angling clubs. They held an annual ball and family picnics. A designated building was developed for the Hume Public Service Club where the Centre workforce of men and women from a variety of nations to could mingle and relax. Their designated club building had a cosy fireside lounge and bar even though alcohol was otherwise barred from the Centre. It had billiard tables and a fancy side-lit dance floor. In return for privilege, staff were required to attend English classes and gain certificates of proficiency.

Many staff stayed for years. Generally they remember the pride they took in their own work and the achievement of the Centre. They dismiss the riots of 1952 and 1961 as disturbances that had been sensationalised by the press. They are loyal to what they saw as worthy and realisable reception centre goals. They counter criticisms of it as a bleak camp of no hope somehow akin to modern-day detention centres. The memories of the long-term resident were deep and often affectionate. A return visit 'feels like coming home'. ${ }^{30}$

Childhood memory provides another category of oral and written testimony that expands on the theme of resilience, but has a darker undertone. David Malouf has recently reminded us that children know the world more sensuously than adults. They have eyes for the immediate detail. Further they are skilled eavesdroppers and voyeurs, sensitive to nuances of language and gesture. He recalls himself as a young person 'an experience machine that observes, thinks, smells, attends, touches' ${ }^{31}$ So, too, those who were children at the Bonegilla Reception Centre had a sensuous awareness of their surrounds and keen insights into adult concerns. 
Children recall fears of sunburn, swooping magpies, nasty spiders, possums, bull ants and snakes. ${ }^{32}$ They remember the perils of deep-pit latrines. They remember food indulgences: milk arrowroot biscuits and loads of bread, butter and jam. They remember their first encounters with a whole pineapple or watermelon and eating Milo dry from the tin. They also remember Bonegilla as part of the adventure of growing up. At Bonegilla, they found companionship readily with other children, often from other nations. Swimming in and exploring around the nearby Lake Hume made it like a holiday camp.

For the young, migration is remembered as a family experience, recalled principally through the prism of parental anecdotes as well as direct observation. Many remember mother crying. Some recall the embarrassment at having strangers speak loudly to their parents as if they were imbeciles. Many remember separation from father when he was required to work elsewhere. Some pick up on the feelings of indignity in having father work in the wood yard or cleaning the toilets at the Centre.

Pino Bosi (Italy 1951) recalls observing the loss of power and status that migration meant for his father:

It was in defeat that I first began to know my father. His defeat started when we came to Australia, though it took me years to realise the significance to him of that sunny afternoon in March 1951 when at Bonegilla Migrant Reception Centre, he was told that the job lined up for him was pushing wheelbarrows for the State Electricity Commission in Melbourne. How must he have felt about being forced to accept work as a labourer, pushing a wheelbarrow, this man of 50, with five children and a wife - a man who, as an engineering contractor in Italy, had hundreds of workers under him, had built roads, public buildings and chairlifts?

It was all right, he said. New country, new life, a sense of excitement. He'd soon get back on his feet. If we didn't like it in Australia, we'd go back home in two years at the completion of our immigration contract. If things went well we'd go home in five, with a bit of money to spare... But it didn't work out like that... ${ }^{33}$ 
Bosi's recall of his father's discomfort illustrates a theme touched on frequently in site visitor book entries. Many come to Block 19 to pay tribute to their parents for the sacrifices they made in migrating to Australia, in search of a better life for themselves and for their children.

Disparate sources yield different insights into refugee and migrant arrival experiences. Anyone trying to unravel the mix of stories that arise in a place that draws on living memory, finds that the 'migrant experience' of the Heritage Park name drifts into 'migrant experiences'. So, for example, the experiences and the memories of the Poles and the Latvians differ from those of the Dutch. Similarly the Greeks and the Italians remember Bonegilla differently from the Swedes and the Danes. Men, women and children remember different things about Bonegilla. Generally those who were competent in English had different arrival and reception experiences from those who were not. The repository of migrant memory material in the Albury LibraryMuseum is essential to understanding the variety of arrival and reception experiences. With them, Bonegilla extends beyond being a collection of huts to becoming a memory place.

\section{PRESENTING A PUBLIC MEMORY PLACE ON POST-WAR IMMIGRATION}

Public attention has been drawn to the importance of immigration with specialist immigration museums in Adelaide and Melbourne. Sydney's Maritime Museum and Melbourne's Station Pier celebrate the landfall of ship-borne immigrants. A virtual museum is managed from Sydney by the Migration Heritage Centre working in close liaison with local government authorities to capture migration stories state-wide. In Canberra there is a proposal for a spectacular pedestrian bridge to honour the contributions made by migrants. The Immigration Bridge will feature memory stories submitted by migrants.

Bonegilla does not have the convenience of capital city access to attract great visitor numbers. It is still out-of-sight and out-of-mind. Perhaps its stories are too bland and unheroic. It was not a massacre site or a detention centre. Its messages do not confront the official in the same way those of the SIEVX temporary exhibition did in Canberra. ${ }^{34}$ Perhaps the challenges to the host society of later waves of more visible migrants from Asia, the Pacific Islands, the Middle 
East and Africa have dwarfed the challenges of receiving the nonBritish in the post-war years.

Still, rhetorical flourishes from Bonegilla insist on drawing parallels with the nation's great rememberings. The military involvement in dealing with unarmed civilians at Bonegilla in 1952 and police quelling of demonstrations by unemployed workers in 1961 have been hailed as 'silenced Eurekas'. ${ }^{35}$ At a ceremony to take possession of the World Youth Day Cross as it travelled through his diocese, the Bishop of Sandhurst, Joe Grech (Malta 1971), waved towards Bonegilla and called for a public apology to post-war migrants: 'We should say sorry because we didn't know how to welcome them' ${ }^{36}$ Preparing an art gallery exhibition, Domenico de Clario (Trieste 1956) arranged the memorabilia of the Bonegilla Collection as an ossuary. His exhibition was a tribute to the 'Unknown Migrant whose bones originate from the numberless micro-narratives of the migrants who passed through Bonegilla' ${ }^{37} \mathrm{I}$, too, draw a war memorial analogy. For me, Block 19 Bonegilla is an uncommon war memorial. In remembering the initial intakes of Europe's displaced, we commemorate the impact of war on civilians uprooted from war zones, rather than the contribution of uniformed warriors.

For Sara Wills, Bonegilla is 'arguably the most remembered of Australia's migrant hostels'. ${ }^{38}$ Heritage visitors may come to tut-tut as they sip tea in the warm parlour of the past. They may poke at national shames from which they wish to distance themselves, but Wills would try for 'productive sadness'. She sees Bonegilla as a 'prehistory' of detention centres and suggests bridges between the two. Such bridges, Wills suggests, are to be traversed cautiously. Like all links between the now and then - even the recent then - they cannot carry heavy loads. But, like her, our visitors do look for contemporary resonances. Some use the site visitor book to rail against asylum seeker detention and the then contentious citizenship test. Block 19 Bonegilla, as I have explained, prompts thinking about how Australia took in and still takes in strangers. ${ }^{39}$

There are parallels with America's Ellis Island, another nation's landfall and processing place. ${ }^{40}$ Commemoration at Bonegilla has been similarly democratic, not singling out those who achieved fame 


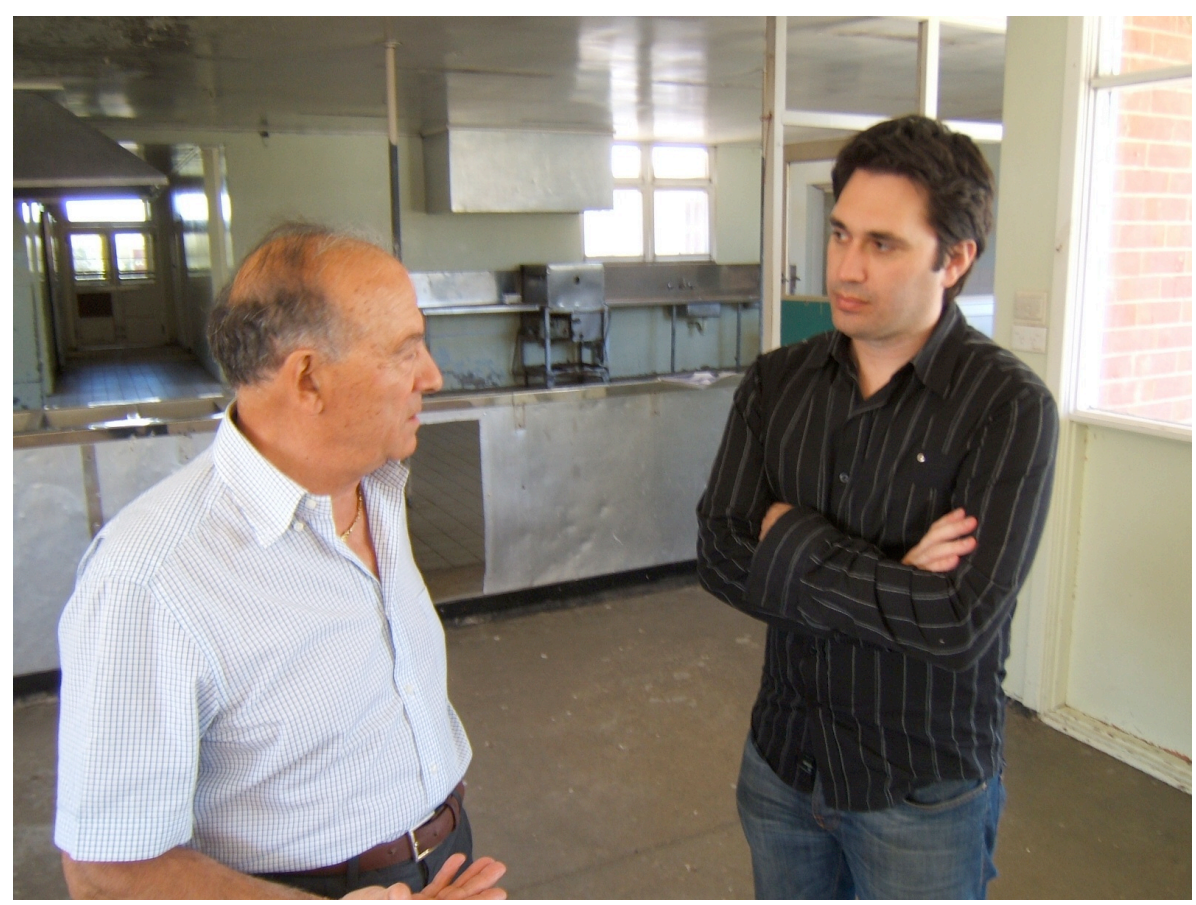

Chris Taylor (right) talks at Bonegilla with Giovanni Sgro (Italy 1952) about the Italian riot in 1952 during the making of a segment on Bonegilla in a television documentary series Australia's Heritage National Treasures by ScreenAustralia, 2008 (Photograph Bruce Pennay)

or social standing. Like a war memorial, the tribute wall of familydonated plaques simply lists the names of ordinary people who contributed to the task of nation-building. ${ }^{41}$

I warm to the notion of memorial representations reflecting Australian understatement and pragmatism. Unlike Ellis Island, no grand statue, bearing a torch, welcomed Europe's tired, poor huddled masses to Bonegilla. Instead, we have repopulated Bonegilla with a cluster of laser-cut steel silhouettes that have weathered into their army camp surrounds. The anonymous two-dimensional figures suggest the fleeting experiences of transients at the site. The man, the children and the huddled woman stare into Australian space like the dog on the tucker box at Gundagai in David Martin's short story. They, too, are a national monument without pretension. ${ }^{42}$

Historians hold no privileged position in management groups, but I do hope the emphasis at the Block 19 site and at the Albury LibraryMuseum remains on probing and presenting a kaleidoscope of refugee, migrant and host society experiences of post-war immigration. I foresee further negotiations of meaning from the 
different points of view of government, locals, diverse ethnic groups and heritage professionals, including historians. We will have a 'fragmented history rather than a smooth whole'. Like the interpreters at Ellis Island, we want to encourage site and museum visitors to engage in reading critically 'a multi-vocal and fragmented heritage landscape'. ${ }^{43}$

It is the records that help us to understand the subjective. ${ }^{44}$ They incite 'the imaginative ability to see strange people as fellow sufferers' ${ }^{45}$ David Malouf argues that shared experiences, shared memories create a true commonwealth of people:

The old fellow in the dark of the cinema behind us who shares our laughter at the antics of $\mathrm{Mr}$ Bean, is an exbomber pilot, or an ex-POW... the woman with her trolley in the supermarket carries in some dark place in her head... a childhood in Auschwitz or the Warsaw Ghetto... The stories these men and women have to tell constitute an alternative history that is also ours; hidden as yet because unspoken, untold... a small revelation of who as Australian we are, in all our variety of experience and fate... In a natural republic the only thing that holds us together and makes us a single nation or people is the bond of feeling, of understanding and affectionate concern that makes neighbours of us.... ${ }^{46}$

With the cultural authority bestowed on us with heritage listings, we are sharing a kaleidoscope of memories at Bonegilla - a public memory place.

\section{ENDNOTES}

${ }^{1}$ A presentation based on this paper was made at the Legacies 09 Conference at the University of Southern Queensland in February 2009. It builds on Glenda Sluga, Bonegilla Place of No Hope, MUP, Melbourne, 1988 and more recent work on migrant accommodation, Ann-Mari Jordens, Redefining Australians: Immigration, Citizenship and National Identity, Hale \& Iremonger, Sydney, 1995, pp43-59 and Mary Hutchison, 'Accommodating strangers: commonwealth government records of Bonegilla and other migrant accommodation centres', in Public History Review, vol 11, 2004, pp63-79. I thank Ann-Mari Jordens and Mary Hutchison for their comments on a draft of this article.

${ }^{2}$ Australian Heritage Database, Register of the National Estate (RNE) Place ID 16157, Place File no.2/08/246/0004 (1991) www.heritage.gov.au/egibin/ahpi/record.pl?RNE16157.Victoria. 
Heritage Register (VHR), no.H1835, File no.607175 (2002)

http:/ / vhd.heritage.vic.gov.au/vhd/heritagevic\#search:simple:user:list:d atabase | places:Bonegilla:1.

National Heritage List (NHL), Commonwealth of Australia Gazette No. S257 (Friday 7 December 2007).

http://www.environment.gov.au/heritage/places/national/bonegilla/in dex.html: all sites accesses 30 July 2009.

${ }^{3}$ G. Hoskins, ' A Place to Remember: Scaling the Walls of Angel Island Immigration Station', Journal of Historical Geography, vol 30, no 4, pp685700.

${ }^{4}$ Bruce Pennay, 'Framing Bonegilla for Tourists and Local Visitors', Historic Environment, vol 21, no 3, October 2008, pp27-33.

${ }^{5}$ Border Morning Mail, 9 September 1983; 14 February; 12 and 17 July; 16 October; 23 November 1985; 16 October 1985; 24 November 1986; 25 April 1988. Sun, Melbourne, 4 April 1986.

${ }^{6}$ Correspondence 24 November 1988 quoted by Ruth Daniell, Freeman Leeson Architects, Block 19 Conservation Management Plan, Department of Defence, Canberra, 1996, p33.

7 Sluga, 1988, op cit, p59. See, for example, Ann Tündern Smith, Bonegilla's Beginnings, Triple D Books, Wagga Wagga, 2007 and http:// www.theage.com.au/interactive/2008/national/migrants/.

${ }^{8}$ In 2009 about 25 places on the NHL are primarily historic sites of 'outstanding significance'.

${ }^{9}$ Peter Marquis-Kyle and Meredith Walker, Illustrated Burra Charter, Australian ICOMOS, 1992/ 2004; Marilyn C Truscott, 'Contexts for Change: Paving the way to the 1999 Burra Charter', Historic Environment, vol 18, no 1, 2004, pp30-34.

${ }^{10}$ John Bodnar, 'Remembering the immigrant experience in American culture', Journal of American Ethnic History, vol 15, no 1, 1995, pp3-25.

${ }^{11}$ For example Ann-Mari Jordens, Alien to Citizen: Settling Migrants in Australia 1945-75, Allen \& Unwin, St Leonards, 1997.

${ }^{12}$ D. and M. Eysbertse, Where Waters Meet, pp20; 28; 30; 39-40.

${ }^{13}$ Anna Burderks quoted in Christopher Keating, A History of the Army Camp and Migrant Camp at Greta, NSW, 1939-60, Uri Windt, Sydney, 1997, p56.

${ }^{14}$ Wanda Skowronska, 'Bonegilla Journey', private publication, c2001, p6, my emphasis.

${ }^{15}$ Interview of Eleonara Connolly by Bruce Pennay, 2008.

${ }^{16}$ For example photo essay Border Morning Mail, 30 December 1960.

${ }^{17}$ For example, Helmut Reichel (Germany 1954), Personal History Data Bank, Albury LibraryMuseum.

${ }^{18}$ Bruce Pennay, Albury-Wodonga's Bonegilla, Albury Regional Museum, Albury, 2001.

${ }^{19}$ Bruce Scates, 'The First Casualty of War', Australian Historical Studies, no 130, 2007, p312.

${ }^{20}$ Glenda Sluga, 'Bonegilla and Migrant Dreaming', in Kate Darian-Smith and Paula Hamilton (eds), Memory and history in twentieth-century Australia, OUP, Melbourne, 1994, pp201; 204.

${ }^{21}$ S. Friedlander, 'History, memory and the historian', in M. S. Roth et al (eds), Disturbing Remains, The Getty Research Institute, Los Angeles, 2001, pp278-79. 
22 ‘National Immigration Museum', brochure, Albury, 1987, Albury LibraryMuseum.

${ }^{23}$ Luke Desforges and Joanne Maddern, 'Front Doors to Freedom, Portal to the Past: History at the Ellis Island Immigration Museum', Social and Cultural Geography, vol 5, no 3, 2004, p453.

${ }^{24}$ N. Peters, Milk and Honey - but No Gold, University of Western Australia Press, Nedlands, 2001, pxiii.

${ }^{25}$ Paul Thompson, The Voice of the Past: Oral History, Oxford University Press, Oxford, 1988, p235.

${ }^{26}$ On the ideology of official heritage, see Paul Ashton, "“The Birthplace of Australian Multiculturalism?": Retrospective Commemoration, Participatory Memorialisation and Official Heritage', International Journal of Heritage Studies, vol 15, no 5, 2009, pp381-98.

${ }^{27}$ For example, Morag Loh (ed), With Courage in their Cases, FILEF, Melbourne, 1980, pp47-50; Commonwealth Parliamentary Debates, 12 August, pp218-219; Giovanni Sgro, Mediterranean Son: Memoirs of a Calabrinian Migrant, Scoprire il Sud, Coburg, 2000.

${ }^{28}$ Carrington, op cit, p42: John Murphy, 'Imagining the Fifties: Private Sentiment and Political Culture', in Menzies' Australia, University of NSW Press, Melbourne, 2000, p158 for the term 'kaleidoscope'.

${ }^{29}$ Marquis-Kyle and Walker, op cit; Michael Cigler (TRC 2536) and David Taylor (TRC 5930/7) have given migrant and resident staff perceptions of how the Centre functioned, oral histories, National Library.

${ }^{30}$ For example, King, a social worker quoted in Sluga, A Place of No Hope, pp94-5 and R. Leovic, letter to the Canberra Times, 7 December 1987.

${ }^{31}$ David Malouf, On Experience, Melbourne University Press, Melbourne, 2008; Inga Clendinnen, 'Only Look, Only See', in The Monthly, September 2008, pp54-7.

${ }^{32}$ I have outlined visitor recall of being young at Bonegilla in 'Welcoming the Young: Bonegilla Remembered', in History, magazine of the Royal Australian Historical Society, no 92, June 2007, pp13-14.

${ }^{33}$ Pino Bosi, 'Requiem for a Migrant Father' Readers', Digest, June 1974, pp56-61 quoted in A. R. Corkhill, The Immigrant Experience in Australian Literature, Academia Press, Melbourne, 1995, p73.

${ }^{34}$ SueAnne Ware, 'Anti-memorials and the art of forgetting', in Public History Review, vol 15, 2008, pp61-70.

${ }^{35}$ Glenda Sluga, 'Bonegilla and Migrant Dreaming', p199.

${ }^{36}$ Howard Jones, 'We need to strive to be the best that we can be', Border Mail, 14 March 2008.

37 'Ossuary', Albury Regional Art Gallery, 2008.

${ }^{38}$ Sara Wills, 'Between the hostel and the detention centre: possible trajectories of migrant pain and shame in Australia', William Logan and Keir Reeves (eds), Places of Pain and Shame: Dealing with Difficult Heritage, Routledge, London, 2009, pp263-80.

${ }^{39}$ Bruce Pennay, So Much Sky, Migration Heritage Centre, Sydney, 2008; 'Reading Block 19 Bonegilla', Albury \& District Historical Society, Albury, 2008.

${ }^{40}$ See, for example, Erica Rand, The Ellis Island Snow Globe, Duke University Press, Durham, 2005.

${ }^{41}$ John Bodnar, 'Remembering the immigrant experience in American culture', Journal of American Ethnic History, vol 15, no 1, 1995, pp3- 25. 
42 'A National Monument', in David Martin, Foreigners, Rigby, 1981, pp35-44.

${ }^{43}$ Desforges and Maddern, op cit, p453.

${ }^{44}$ 'Metaphors of Self in History: Subjectivity, Oral Narrative and Immigration Studies', in Virginia Yans McLaughlin (ed), Immigration

Reconsidered: History, Sociology and Politics, Oxford University Press, New York, 1990, pp254-92.

${ }^{45}$ Richard Rorty quoted in Inga Clendinnen, 'Fellow Sufferers: History and Imagination', in Australian Humanities Review, September 1996.

${ }^{46}$ Malouf, op cit, p30. 